\begin{tabular}{|c|c|c|c|c|c|c|}
\hline \multirow{4}{*}{ Impact Factor: } & ISRA (India) & $=3.117$ & SIS (USA) & $=0.912$ & ICV (Poland) & $=6.630$ \\
\hline & ISI (Dubai, UAE & $=0.829$ & РИНЦ (Russia) & $=0.156$ & PIF (India) & $=1.940$ \\
\hline & GIF (Australia) & $=0.564$ & ESJI (KZ) & $=8.716$ & IBI (India) & $=4.260$ \\
\hline & JIF & $=1.500$ & SJIF (Morocco) & $=5.667$ & OAJI (USA) & $=0.350$ \\
\hline
\end{tabular}

\section{SOI: $1.1 /$ TAS $\quad$ DOI: $10.15863 /$ TAS International Scientific Journal Theoretical \& Applied Science}

\author{
p-ISSN: 2308-4944 (print) e-ISSN: 2409-0085 (online) \\ Year: 2019 Issue: $05 \quad$ Volume: 73
}

Published: $25.05 .2019 \quad \underline{\text { http://T-Science.org }}$
QR - Issue

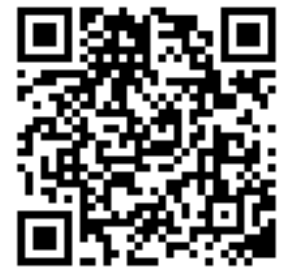

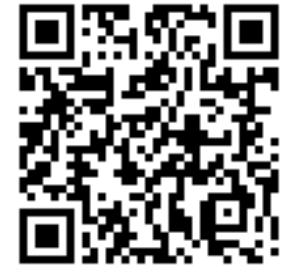

D.R. Yusupova

Tashkent State University of Uzbek language and literature named after Alisher Navoi. Uzbekistan.

\title{
COMPARISON OF PROSODY USED IN THE WORKS BY ALISHER NAVOI AND ABDURAKHMAN JAMI
}

\begin{abstract}
In the literary environment of Hirat in XV century aruz as a scientific and theoretical science reached its peak. Works related to prosody were studied by Abdurakhman Jami in his "Risala-i Aruz" and "Mezan-ul Avzan" by Alisher Navoi. They are the best scholars who developed great significan works on prosody. Jami's "Risala-i Aruz" served as a primary source for the work of Alisher Navoi, who made use of various sources on aruz in PersianTajik literature. According to Navoi, no work on the theory of aruz in Turkic literature had been written before Alisher Navoi. So, the purpose of Navoi was to analysis more complete by such literary styles as bahrs, rukns, wazns and doiras. His work is perfect and it has much information on Turkic literature. Both scholars had similar opinions on the chapters of aruz-juzv, zihof and furu'. Both Navoi and Jami developed 6 juzvs, 45 zihofs and 60 furu's. Abdurahmon Jami describes four doiras but mostly researched contemporary aruz studies in "Al-Mu'jam", in particular. Alisher Navoi adds three more doiras and starts the tradition of poetry writing in two devices - komil in "Doirai Mukhtalita" and tawil in "Doirai Mushtahiba" which were described by him as matbu' (pleasant).

Key words: aruz (prosody), bakhr (metrical form), vazn (meter), rukn (feet), juzv (the smallest unit of aruz), zikhof (changes), furu', doira (circle).

Language: English

Citation: Yusupova, D. R. (2019). Comparison of prosody used in the works by Alisher Navoi and Abdurakhman Jami. ISJ Theoretical \& Applied Science, 05 (73), 281-285.
\end{abstract}

Soi: http://s-o-i.org/1.1/TAS-05-73-40 Doi: crossef https://dx.doi.org/10.15863/TAS.2019.05.73.40

\section{INTRODUCTION:}

The Poems were written in prosody by poets of the Muslim East. So, they were first studied and introduced by the Arab scientist Khalil ibn Akhmad ${ }^{l}$, and further developed by such scholars as Akhfash ${ }^{2}$,

${ }^{1}$ Khalil ibn Akhmad al-Farahidi (715/719 - 786/791) was the founder of aruz studies. Fragments of his "Kitob ulAyn" have reached us. His "Ar-Risala fi-Ma'n al-Huruf" ("Treatise on the meaning of letters"), which has also reached us, was published in 1969 in Cairo. There is information that he created "Risalai Aruz" about aruz; however, it has not reached us.

${ }^{2}$ Abul Khasan Akhfash Balkhi (died 835) was an Arab linguist who studied aruz. After Khalil ibn Akhmad, he further developed the science of aruz, and introduced bahr of mutadorik.

${ }^{3}$ Abu Zakariya al-Khatib Tabrizi was an Arab scholar who studied aruz. His "Risala fil Aruz va Qafiya" on the theory of aruz and rhyme has reached us.

${ }^{4}$ Makhmud Zamaxshari $\left(11^{\text {th }} \mathrm{c}\right.$.) was a literary critic from Khorezm, the author of "Aruzi Qustas" on the theory
Abu Zakariya al-Khatib Tabrizi ${ }^{3}$ and Makhmud Zamaxshari $^{4}$.

It was in the $13^{\text {th }}-15^{\text {th }}$ centuries when aruz as a scientific and theoretical science reached its peak. Works of such scholars as Shams Qays Razi ${ }^{5}$, Nasiriddin Tusi ${ }^{6}$, Vakhid Tabrizi ${ }^{7}$, Yusuf Azizi ${ }^{8}$,

of poetry. Following the traditions of the time, his work was written in Arabic.

${ }^{5}$ Shams Qays Razi (13 ${ }^{\text {th }} \mathrm{c}$.), one of the founders of studies of Persian aruz, was born in the city of Ray in Persia. He was the author of such works as "Al-Mu'jam" on aruz and "Al-Mu'rab" on Arabic literature.

${ }^{6}$ Nasiriddin Tusi $\left(13^{\text {th }} \mathrm{c}\right.$.), a Persian writer and thinker, was the author of "Me'yar ul-Ash 'ar" that consists of an introduction and two large parts on aruz and rhyme.

${ }^{7}$ Vakhid Tabrizi (the end of $14^{\text {th }} \mathrm{c}$. - the beginning of $15^{\text {th }} \mathrm{c}$.), a Persian poet and literary critic, was born in the city of Tabriz in Persia. His works on literary studies and on aruz in particular "Miftoh ul-bado' $i$ " and "Jam'-i-mukhtasar" have reached us.

${ }^{8}$ Yusuf Azizi $\left(15^{\text {th }} \mathrm{c}\right.$.) was a Persian poet and scholar of aruz studies. He lived most of his life in Herat. The influence 


\begin{tabular}{|c|c|c|c|c|c|c|}
\hline \multirow{4}{*}{ Impact Factor: } & ISRA (India) & $=3.117$ & SIS (USA) & $=0.912$ & ICV (Poland) & $=6.630$ \\
\hline & ISI (Dubai, UAI & $=0.829$ & РИНЦ (Russia & $=0.156$ & PIF (India) & $=1.940$ \\
\hline & GIF (Australia) & $=0.564$ & ESJI (KZ) & $=8.716$ & IBI (India) & $=4.260$ \\
\hline & JIF & $=1.500$ & SJIF (Morocco & $=5.667$ & OAJI (USA) & $=0.350$ \\
\hline
\end{tabular}

Abdurakhman Jami, Sayfi Bukhari ${ }^{9}$, Ataullah Khusaini $^{10}$, Shaykh Akhmad TaRazi ${ }^{11}$ and Alisher Navoi, created during that period, are of special importance because of their deep and complete analysis of theoretical bases of aruz. Among these works, "Risala-i Aruz" by Abdurakhman Jami and "Mezan-ul Avzan" by Alisher Navoi are of a great significance.

\section{LITERATURE REVIEW:}

It is a well-known fact in the academic doiras of today that Navoi and Jami held similar views and opinions and were partners in many aspects of literary and scientific work. Their works were created almost at the same time. They are: "Hamsa", "Nafohat ulUns" and "Nasaim ul-Muhabbat" devoted to the followers of the Sufi order ${ }^{12}$, "Risala-i Muamma" about the rules of solving the genre of mu'ammo (puzzle), philosophical works "Lujjat ul-Asrar" and "Tukhfat ul-Afkar" can illustrate this. Their works "Risala-i Aruz" and "Mezan ul-Avzan" devoted to the analysis of the theory of aruz are also the results of such scholarly works.

It is not known when Jami wrote "Risala-i Aruz ${ }^{\prime \prime 13}$. The fact that the work contains verses from Khaja Ismatullah Bukhari ${ }^{14}$ and refers to him as "rakhmatulloh" (May Allah bless him and grant him peace) indicates that it was written after the death of the latter, that is, the second half of the $15^{\text {th }}$ century [1, p. 202]. The treatise conseders the most important issues concerning Persian aruz. This is due to the fact that many works on the rules of Persian aruz had been created before Jami, including "Al-Mu'jam" by Shams Qays Razi, "Me'yar ul-Ash'ar" and "Jam'i Mukhtasar" by Vakhid Tabrizi.

"Mezan ul-Avzan"ls by Alisher Navoi was written in 1492 - 1493, after the death of Jami. Unaware of Shaykh Akhmad Tarazi's "Funun ulBalagha" devoted to the literary studies in Turkic, Navoi points out that it was he who first attempted to

of Shams Qays Razi's "Al-mu'jam" can be traced in his "Aruzi Yusuf" dvoted to aruz studies.

${ }^{9}$ Sayfi Bukhari (died 1503) was a Persian poet and literary critic, the author of "Aruzi Sayfi", "Risala- $i$ Mu'ammo", "Risala-i Musiqi". His "Aruzi Sayfi" and "Divan" (collection of poetry) have reached us.

10 Ataullokh Khusaini (died 1513) was a Persian scholar and literary critic, the author of "Badoe' ul-Samoe"," on Persian aruz and stylistic devices, written by the suggestion from Alisher Navoi in 1493.

${ }^{11}$ Shaykh Akhmad Tarazi $\left(15^{\text {th }} \mathrm{c}\right.$.) was a Turkic scholar who studied poetry. His "Funun ul-Balogha" (written in 1436 - 1437) devoted to the ruler and astronomer Ulugh Bek (1394 - 1449), a descendant of Tamerlane, has reached us. The work consists of parts covering poetical genres, rhyme, radif, poetical devices, aruz and mu'ammo. The last part on mu'ammo has been lost.

12 Alisher Navoi's "Nasaim ul-Muhabbat" ("The breezes of love") is a free translation of Abdurakhman describe the rules of the theory of aruz in Turkic, and no such work had been done before. In particular, he writes, "The purpose of this work is to show that poetry in Turkic has appeared; however, the rules for Turkic poetry have not been worked out”. [2, p. 43]

Also, in the introduction to his work, Navoi refers to some works on aruz created before him "Kitab ul-Ayn" by Khalil ibn Akhmad, "Al-Mu'jam" by Shams Qays Razi, "Me'yor ul-Ash'ar" by Nasiriddin Tusi and "Risala-i Aruz" by Abdurakhman Jami and says that some doiras (circles) and vazns (meters) which are not mentioned in these works will also be considered.

\section{MATERIALS:}

"Mezan ul-Avzan" starts with hamd (the lines praising Allah) and na't (the lines praising Prophet Muhammad). It is said in the book that Husain Baykara inspired Navoi to write it. Navoi describes aruz as a sacred science, stating that some verses from the Koran and some quotes from hadith (sayings of Prophet Muhammad) match the metre of aruz, and many poems from "Divan" (collection of poetry) of Hazrat Ali were written in aruz. Then, Navoi provides some information on the founder of aruz Khalil ibn Akhmad and the term itself. Only after this Navoi goes on to describe the theoretical rules of aruz. In contrast, Jami provides the description of rules of aruz right after the lines praising Allah. As stated above, this is due to the fact that there had been works on aruz before Jami.

Both works first provide information on the smallest unit of aruz - juzv and use the term "rukn" (or the foot) for it [3, p.75]. Both authors think that there exist six rukns: light and heavy sabab, joint and separated watad and little and big fosila.

After juzvs, both authors consider "real rukns" - they are referred to "asl" or "usul" and state that there are eight of them, as following: Faulun ( $\mathrm{V}--)$; Foilun (- V -); Mafoiylun ( $\mathrm{V}---)$; Mustaf'ilun (-

Jami's "Nafahat ul-Uns" ("The flavor of friendship"). It contains information on the life of the followers of the Sufi order. During the translation Navoi enriched Jami's original work, adding some new information

${ }^{13}$ The edition of "Risala-i Aruz" in vol. 8 of the eightvolume collection of Jami's works (Abdirahmani Jami. Osor. Jildi 8) published in 1990 in Dushanbe, Tajikistan, has been used in preparing this article.

${ }^{14}$ Khaja Ismatullah Bukhari (the end of 14c. - the beginning of $15^{\text {th }} \mathrm{c}$.) was a famous bilingual (Turkic and Persian) poet. He lived in Mawerannahr (Transoxania). His "Divan" (collection of poetry) including fifteen genres and poem "Ibrahim Adham" have reached us.

${ }^{15}$ The edition of "Mezan ul-Avzon" in vol. 16 of the 20-volume complete collection of Navoi's works published in 2000 by the Institute of Language and Literature of the Academy of Sciences of the Republic of Uzbekistan has been used in preparing this article. 


\begin{tabular}{|c|c|c|c|c|c|c|}
\hline \multirow{4}{*}{ Impact Factor: } & ISRA (India) & $=3.117$ & SIS (USA) & $=0.912$ & ICV (Poland) & $=6.630$ \\
\hline & ISI (Dubai, UAE & $=0.829$ & РИНЦ (Russia & $=0.156$ & PIF (India) & $=1.940$ \\
\hline & GIF (Australia) & $=0.564$ & ESJI (KZ) & $=8.716$ & IBI (India) & $=4.260$ \\
\hline & JIF & $=1.500$ & SJIF (Morocce & $=5.667$ & OAJI (USA) & $=0.350$ \\
\hline
\end{tabular}

$-\mathrm{V}-$ ); Foilotun (- V --); Mafoilatun ( $\mathrm{V}-\mathrm{V} \mathrm{V}-$ ); Mutafoilun (V V - V -); Maf'ulotu (--- V).

Both auhors provide definitions for only five of the above mentioned. According to Jami, only five rukns are peculiar to original Persian poetry, while Navoi states that they are widely used in Turkic poetry as well.

After the definition of asls, authors continue to describe zihof (modifications of asls) and furu' (special rukns), both developed from asls. Both Navoi and Jami consider that there are 45 zihofs, compared to 35 in "Al-Mu'jam"'l6, 35 in "Funun ul-Balagha"17 [4, p.80-a] and 44 in "Mukhtasar"18 [5, p.19].

\section{METHOD:}

Then, the authors consider doiras (circles). A doira in aruz is a group of similar bahrs. Based on doiras described in "Al-Mu'jam", Jami considers four of them: "Doirai Mu'talifa" (consists of ramal, hazaj and rajaz bahrs), "Doirai mukhtalifa" (consists of muqtazab, mujtass, munsarih and muzore' bahrs), "Doirai Muntazia” (consists of mushokil, sari', jadid, qarib and hafif bahrs), "Doirai Muttafiqa" (consists of mutaqorib and mutadorik bahrs). [6, p. 50]

Alisher Navoi considers seven doiras. The first four of them are the same as described by Jami. The fifth doira, "Doirai Mujtamia", is invented by Navoi by putting together nine solim (not modified) rukns of nine bahrs - four bahrs of the second doira and five bahrs of the third doira.

The sixth doira, "Doirai Mukhtalita", according to Navoi, consists of komil and vohir bahrs. Navoi mentions that these bahrs are matbu' (pleasant), though they are not widely used in poetry and are not streamlined. So, this doira is also Navoi's contribution to aruz studies. The seventh doira consists of three bahrs - tavil, madid and basit; and according to Navoi, they are peculiar to the Arabic literature, and are not used in other nation's poetry.

Thus, it can be seen that Jami in his work considers only those bahrs that were used in poetry of the period and describes doiras connected with them, while Navoi adds three more doiras and provides their extended analysis.

After the analysis of doiras, both authors consider bahrs. They are considered in the order of doiras to which they belong. Jami considers 14 bahrs, while Navoi analyses 19 of them. As stated above, while Jami considers only those bahrs that are widely used in Persian poetry, Navoi analyses, in addition to those 14 bahrs, also komil, vofir, tawil, madid and basit bahrs and shows that it is possible to use them in writing poetry in Turkic. In particular, Navoi's own collection of poetry "Khazain ul-Ma'ani" includes ghazals (lyric poems) written in komil and tawil bahrs.

\section{DISCUSSION:}

After the general description of bahrs, meters are considered. In his treatise, Jami provides two examples from $R u d a k i^{19}$, one example from Khaja Jamaliddin Salman ${ }^{20}$ and one example from Khaja Ismatullah Bukhari. Of a special interest are verses from Khaja Ismatullah Bukhari. Jami brings his following verses to illustrate poetical foot of mutaqoribi maqbuzi aslam consisting of sixteen rukns:

Zihy du chashmat ba xuni mardum kushoda tiru kashida xanjar

Fau'lu fa'lun fau'lu fa'lun fau'lu fa'lun fau'lu fa'lun

Ruxi chu mohat sabohi davlat, xati siyohat shabi muanbar.

(Its translation:

Alas, to shed folks blood your two eyes are shooting arrows and drawing daggers

The tender hair on your lips is a flavoring night).

All other examples are written by Jami himself. The number of all meters in the treatise is about 157 .

Jami's bahrs and meters can be seen in the following table:

Table 1

\begin{tabular}{|c|l|l|l|l|c|}
\hline \multirow{2}{*}{ № } & \multirow{2}{*}{ Names of bahrs } & \multicolumn{3}{|c|}{ Number of meters } & \\
\cline { 3 - 6 } & & Eight-foot meters & Six-foot meters & Four-foot meters & Total \\
\hline 1. & Khazaj & $\begin{array}{l}10 / 24 \\
\text { (meters of rubai) }\end{array}$ & 14 & 4 & 52 \\
\hline 2. & Rajaz & 7 & 6 & 2 & 15 \\
\hline 3. & Ramal & 7 & 5 & 2 & 14 \\
\hline
\end{tabular}

16 Shams Qaysi Razi. Al-Mu’jam. / Prepared for publication by U.Toirov. - Adib Publishing House, Dushanbe, 1991. p.50.

17 Shaykh Akhmad Khudoydod Tarazi. Funun ulBalogha. / Prepared for publication by A.Hayitmetov. Khazina Publishing House, Tashkent, 1996. p.151.

18 Zakhiriddin Muhammad Babur. Mukhtasar. / Prepared for publication by S.Hasanov. - Fan Publishing House, Tashkent, 1971. p.19.
19 Abu Abdullah Ja'far Muhammad Rudaki (858 941) was the founder of Persian literature. Extracts from his poem "Kalila and Dimna" and more than 2,000 lines of verses have reached us. In his time, Rudaki was famous as "Adam ush-Shu'ara" (“Adam of poets").

${ }^{20}$ Khaja Jamaliddin Salman Savaji (1310 -1376) was a famous Persian poet. His poems "Jamshid and Khurshid" and "Firoqnoma" as well as a collection of 16.000 lines of verses have reached us. 


\begin{tabular}{|c|c|c|c|c|c|c|}
\hline \multirow{4}{*}{ Impact Factor: } & ISRA (India) & $=3.117$ & SIS (USA) & $=0.912$ & ICV (Poland) & $=6.630$ \\
\hline & ISI (Dubai, UAE & $=0.829$ & РИНЦ (Russia & $=0.156$ & PIF (India) & $=1.940$ \\
\hline & GIF (Australia) & $=0.564$ & ESJI (KZ) & $=8.716$ & IBI (India) & $=4.260$ \\
\hline & JIF & $=1.500$ & SJIF (Morocce & $=5.667$ & OAJI (USA) & $=0.350$ \\
\hline
\end{tabular}

\begin{tabular}{|l|l|l|l|l|l|}
\hline 4. & Munsarih & 7 & 2 & 2 & 11 \\
\hline 5. & Muzori & 8 & 4 & - & 12 \\
\hline 6. & Muqtazab & 2 & - & 4 & 6 \\
\hline 7. & Mujtass & 7 & - & 2 & 9 \\
\hline 8. & Sari & - & 6 & - & 6 \\
\hline 9. & Jadid & - & 1 & - & 1 \\
\hline 10. & Qarib & - & 3 & - & 3 \\
\hline 11. & Xafif & 1 & 7 & - & 8 \\
\hline 12 & Mushokil & 1 & 1 & 2 & 4 \\
\hline 13. & Mutaqorib & 7 & 2 & $-/$ Mutatavval & 10 \\
\hline 14. & Mutadorik & 4 & 2 & - & 6 \\
\hline & Total & $\mathbf{8 5}$ & $\mathbf{5 3}$ & $\mathbf{1 9}$ & \\
\hline
\end{tabular}

The number of all meters in Navoi's work is around 160, and like in Jami's treatise, all examples are written by Navoi himself. Only in the part of treatise concerning folklore genres one example is from Husain Baykara ${ }^{21}$ and one example is from "Muhabbatnoma",22.

Navoi's bahrs and meters can be seen in the following table:

Table 2

\begin{tabular}{|c|c|c|c|c|c|}
\hline \multirow[t]{2}{*}{ № } & \multirow[t]{2}{*}{ Names of bahrs } & \multicolumn{3}{|c|}{ Number of meters } & \multirow[b]{2}{*}{ Total } \\
\hline & & Eight-foot meters & Six-foot meters & Four-foot meters & \\
\hline 1. & Khazaj & $\begin{array}{l}11 / 24 \\
\text { (meters of rubai) }\end{array}$ & 10 & 1 & 46 \\
\hline 2. & Rajaz & 6 & 6 & 1 & 13 \\
\hline 3. & Ramal & 7 & 4 & 2 & 13 \\
\hline 4. & Munsarih & 8 & 3 & 2 & 13 \\
\hline 5. & Muzori' & 8 & 5 & - & 13 \\
\hline 6. & Muqtazab & 2 & 1 & 4 & 7 \\
\hline 7. & Mujtass & 7 & 1 & 2 & 10 \\
\hline 8. & Sari' & - & 6 & - & 6 \\
\hline 9. & Jadid & - & 2 & - & 2 \\
\hline 10. & Qarib & - & 4 & - & 4 \\
\hline 11. & Xafif & - & 6 & - & 6 \\
\hline 12 & Mushokil & 1 & 2 & 2 & 5 \\
\hline 13. & Mutaqorib & 8 & 2 & - / Mutatavval & 10 \\
\hline 14. & Mutadorik & 4 & 3 & - & 7 \\
\hline 15. & Komil & 1 & - & - & 1 \\
\hline 16. & Vofir & 1 & - & - & 1 \\
\hline 17. & Tavil & 1 & - & - & 1 \\
\hline 18. & Madid & 1 & - & - & 1 \\
\hline 19 & Basit & 1 & - & - & 1 \\
\hline & Total & 91 & 55 & 14 & 160 \\
\hline
\end{tabular}

Thus, comparative analysis of "Mezan ulAvzan" by Alisher Navoi and "Risala-i Aruz" by Abdurakhman Jami enables us to draw the following conclusions:

\section{ANALYSIS:}

${ }^{21}$ Husayn Baykara (1438 -1506) was a descendant of Tamerlane, the ruler of Khorasan from 1469 to 1506 . He wrote some poetry as well. His "Risala" written in prose (1486) and a collection of poetry have reached us.

22 "Muhabbatnoma" is a poem written by Khorazmi, a poet who lived in the $14^{\text {th }} \mathrm{c}$. Written in $1353 / 54$ and
"Risala-i Aruz" by Jami served as the primary source for the work of Alisher Navoi, who made use of various sources on aruz in Persian-Tajik literature [7, p.78].

The purpose of Alisher Navoi was to analyse more completly bahrs, rukns, wazns (meters) and doiras (circles). Jami concentrated more on bahrs and

consisting of eleven nomas - letters written by a lover to his beloved one, this poem was devoted to Muhammad Khujabek, a nobleman from the court of Jonibekkhon, the ruler of the Golden Horde from 1342 to 1375. 


\begin{tabular}{|c|c|c|c|c|c|c|}
\hline \multirow{4}{*}{ Impact Factor: } & ISRA (India) & $=3.117$ & SIS (USA) & $=0.912$ & ICV (Poland) & $=6.630$ \\
\hline & ISI (Dubai, UAI & $=0.829$ & РИНЦ (Russia & $=0.156$ & PIF (India) & $=1.940$ \\
\hline & GIF (Australia) & $=0.564$ & ESJI (KZ) & $=8.716$ & IBI (India) & $=4.260$ \\
\hline & JIF & $=1.500$ & SJIF (Morocco & $=5.667$ & OAJI (USA) & $=0.350$ \\
\hline
\end{tabular}

doiras actual in his time, as "Al-Mu'jam" by Shams Qays Razi, "Me'yor ul-Ash'or" by Nasiriddin Tusi [8, p. 31-34] and "Jami'i Mukhtasar" by Vakhid Tabrizi created before Jami were also devoted to aruz studies in Persian-Tajik literature.

Both authors had similar opinions on the units of aruz - juzv, zihof and furu'. Both Navoi and Jami bring 6 juzvs, 45 zihofs and 60 furu's.

Abdurakhman Jami describes four doiras and mostly considered contemporary aruz in " $\mathrm{Al}$ Mu'jam”, in particular. Alisher Navoi adds three more doiras and starts the tradition of poetry writing in two devices - komil in "Doirai Mukhtalita" and tawil in "Doirai Mushtahiba", described by him as matbu' (pleasant).

\section{RECOMMENDATIONS:}

The fact that many poems in Navoi's collection "Khazoin ul-Ma'oni" were written in these doira devices and many poets after Navoi - Munis Khorazmi $^{23}$, Ogahi $^{24}$, Uvaysi ${ }^{25}$, Fazli $^{26}$ and others used them in their poetry writing proves the fact that these doiras are convenient for poetry writing purposes in the Turkic language.

Abdurakhman Jami describes 14 bahrs and about 150 meters in his work "Risala-i Aruz", while Navoi analyses and illustrates 19 bahrs and 160 meters in his work "Mezan ul-Avzan".

Both writers referred to their own poetry while illustrating and explaining aruz system, which shows that both of them were not only theoreticians, but also practitioners of aruz studies.

\section{References:}

1. Jami, A. (1990). Risolai aruz. Artworks: 8 volumes. Vol 8. Dushanbe: Adib, p.496.

2. Navoiy, A. (2000). Mezon ul-avzon. TAT. 20 volumes. Vol 16, Tashkent: Fan, p.338.

3. Musulmonkulov, R. (1989). Persian-tajik classic poetry (X-XV cc.). (p.240). Moscow: Nauka.

4. Shaykh, A. X. T. (n.d). Funun al balaghah (kept in Bodlion library, Eliott \# 127 manuscript).

5. Babur, Z. (1971). Mukhtasar (Introduction) / Prepared for publication by S.Hasanov. (p.240). Tashkent: Fan.
6. Shams, Q. R. (1991). Al-Mu'jam. / Prepared for publication by U.Toirov. Adib Publishing House, Dushanbe.

7. Simidchieva, M. (2003). Imitation and Innovatsion in Timueid Poetics: Kashifi's Badayi al-afkar and Predecessors, al-Mu'jam and Hada'iq al-sihr / Iraninan Studies, volume 36, number 4, December.

8. Tusi, N. (1992). Me'yor ul-ashor / Prepared for publication by U.Toirov. Oryono Publishing House, Dushanbe.
${ }^{23}$ Shermuhammad Munis Khorazmi (1778 - 1829) was an Uzbek poet, historian and hydrologist, well known for his collection of poetry "Munis ul-ushshoq", a historical work "Firdaws ul-Iqbal" and translations from "Ravzat us-Safa" by Mirkhand.

${ }^{24}$ Muhammad Reza Ogahi (1809 - 1874) was an Uzbek poet, historian, translator and hydrologist, the nephew of Munis Khorazmi. He ranks second after Alisher Navoi in Uzbek literature by the number of works he created. His collection of poetry "Ta'viz ul-Ashiqin", 6 historical works and 19 translations have reached us.

25 Jahanatin Uvaysi $(1789 / 90$ - 1850) was an Uzbek poetess. Her collection of poetry and three poems "Chronicles of Muhammad Alikhon" (uncompleted), "Prince Hasan" and "Prince Husayn" have reached us.

${ }^{26}$ Fazli Namangani was one of the leading poets of Kokand literary circle. He served in the court of the ruler of Kokand Amir Umarkhan (1787 - 1822) and created an anthology "Majmua-i Shairan" by the order of Umarkhan. 